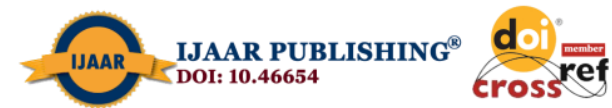

International Journal of Advanced Academic Research (Arts, Humanities and Education) | ISSN: 2488-9849

Vol. 6, Issue 11 (November, 2020) | www.ijaar.org

Journal DOI: 10.46654/ij.24889849

Article DOI: 10.46654/ij.24889849.a6101119

\title{
INCULCATING THE SKILLS OF IMPROVISATION IN PRIMARY SCHOOL PUPILS THROUGH THE PROJECT METHOD OF TEACHING BASIC SCIENCE AND TECHNOLOGY EDUCATION
}

\author{
${ }^{1}$ Onoja, A. I., Ph.D; ${ }^{2}$ Okere, C. S.; ${ }^{3}$ Emeronye, R. U.; ${ }^{4}$ Nwuke, U and ${ }^{5}$ Ugochukwu, M.G \\ ${ }^{1,3}$ Department of Basic Sciences, \\ ${ }^{2,4,5}$ Department of Biology, \\ 1,2,3,4,5 Alvan Ikoku Federal College of Education, Owerri, Imo State, Nigeria.
}

\begin{abstract}
The emphasis of the current Basic Science and Technology Education (BSTE) curriculum is on activity-oriented approach to teaching and learning which is child centered. The implication of child centered learning is that each pupil should be provided with the necessary materials to participate in the teaching and learning process. The increasing enrollment of pupils in primary schools place a lot of demands on proprietors and school administrators in the provision of necessary facilities for the implementation of the Basic Science and Technology Education curriculum. This write up unveil the secrets of the project method of teaching in supplementing facilities for Basic Science and Technology teaching with improvised materials particularly in primary schools. The process involves the development of skills in the learners such as questioning, manipulation, measurement, design and modeling to create equipment using local resources available in the environment. The role of the teacher is to create enabling environment for the pupils to acquire and demonstrate these skills. The use of local materials in improvising science equipment demystifies the notion that science is foreign and consequently triggers the innate curiosity of pupils to learn. The provision of good working condition for teachers and encouragement of pupil who have exhibited outstanding skills in designing equipment are advocated to promote the project method in improvisation.
\end{abstract}

Keyword: Improvisation, Project method, Basic Science \& Technology 


\section{Introduction}

Science education emphasizes hand-on, mind-on, activity based and child centered method of teaching. One of the objectives of Universal Basic Education (UBE) and the present Sustainable Development Goals (SDG's) emphasize equal education opportunities for all children of school age. One of the objectives of basic (primary) science education according to the National Policy on Education (FRN, 2013) is to lay a sound basis for scientific and reflective thinking. Since primary school pupils have the ability and capability to think and reason, teachers of primary science should realize that problem solving may be developed through several stages. Thus, primary science teachers should do everything possible to help children think clearly, critically and creatively. These they can do by creating an intellectual environment where the children should be free to work out solutions to address their learning difficulties. Science teaching and learning involves human activities which employ the activity approach to teaching and learning. It is expected that the pupils' immediate environment should be used to obtain the major resources for improvisation in the teaching and learning of science at the primary school level.

In the present dispensation in which every region of the Nigerian populace have realized the importance of education and there are lots of children to be taught in primary schools, the following instructional approaches may be used to salvage the teaching and learning of basic (primary) science at the lower basic level of education. These approaches include but not limited to; development of science process skills in pupils, improvisation of instructional materials/equipment with the use of immediate local environmental resources. Basic primary science is activity based and requires a lot of materials for its instruction. Consequently, the teacher may not necessarily depend on standard apparatus for its teaching. Instructional materials whose resources may be obtained from the environment should be improvised.

Yero and Bello (2010) maintain that the child's immediate local environment have good resources that can be used for teaching science at the basic lower level of education. Science, particularly at this level relies on process approach of teaching which involves observation, identification, classification, manipulation, experimentation and so on. The immediate environment should be properly utilized through sourcing for raw materials that could be used for improvisation. Improvisation may be viewed as the act of using available teaching materials and resources whenever there is lack or shortage of actual teaching or instructional materials to enhance the teaching and learning process. Improvisation is not just to provide material substitute for what is not available, but whatever is improvised must serve the purpose for which it is intended. Onoja, Azoro and Egeruoh (2012) pointed out that improvisation is the act of designing a replica of something to make it function or play the role of the real thing using available materials. Improvisation in science teaching may equally mean the act of using alternative materials and resources to facilitate instruction whenever the desired instructional materials are out of reach. Improvisation becomes necessary when the desired instructional materials are lacking. In this situation, the science teacher has to look into the environment to see if the materials in the environment could be used to serve the same purpose in the instructional process. Oyediram (2010) viewed improvisation as the act of using materials or equipment obtained from local environment or designed either by the teacher with the help of local 
personnel (artisans) to enhance instruction. The teacher may not be able to carry out the art of improvisation single handedly but may require the services of a technician to improvise the materials or equipment needed. Similarly, in collection of resources from the environment, there should be good relationship or synergy between the teacher, the pupils and members of the immediate community. Where such relationship exists, the task of improvisation becomes less cumbersome.

Every improvised material must aim at specific teaching and learning task but not just for the sake of boosting the ego of the teacher. Madubine and Ikwuanusi (2007) opined that improvisation may be funny when bringing such materials into the classroom may be difficult due to its size or because of the dangerous implications. For instance, it will be unreasonable and dangerous to bring a mad man into the classroom just to teach insanity. It could also be disastrous when bringing live snakes to the classroom to teach reptiles. Similarly, hippopotamus may be difficult if not impossible to be brought into the classroom for instruction. An improvised material that makes the teacher look like a magician without any theoretical and practical relevance is a waste of both the teachers' and the learners' time.

Improvisation should aim at expanding learning options, and combination of instructional strategies. They may be several reasons for improvising instructional materials. Improvised materials may reveal to both the teacher and the pupils that science can be interesting and can be studied by almost everyone. It has the ability of revealing to the pupils that science can be studied without a room called laboratory, particularly when local materials are used. Improvisation shows the relevance of local materials to teaching and learning (Yero \& Bello, 2010). Improvisation should not only assist in teaching but also help the teacher to manage both the learner and the learning environment. The use of improvised materials in teaching and learning should be able to create a change in the behavior of the pupils which is the goal of the instructional process.

\section{The project method of teaching and scientific skills acquisition by primary school pupils}

The project method of teaching centers on an assignment of interest undertaken by an individual or a group of pupils or the whole class. In this method of teaching, the pupils are given a free hand to perform an assigned task with the teacher serving as a guide only when necessary. For instance, pupils may be asked to prepare dye from the leaves of a named plant. The teacher provides the step for carrying out the exercise to the pupils and watches them as they carry out the assignment and later discuss the result with them. This strategy provides opportunities for pupils to develop their initiatives as a greater understanding of how to learn. Motivation to work in project method of teaching is high since it is based on the innate interest of pupils. The project method of teaching therefore offers opportunity for independent work and helps the pupil to gain in-depth knowledge of a specific task. It affords pupils opportunity for developing leadership and organizing ability. For effective utilization of the project method in teaching and learning, it is necessary to clarify the purpose of the project and necessary guidelines to avoid much waste of time on the part of the pupils. The science teacher should provide the pupils with necessary assistance while monitoring the pupils at specific intervals to avoid much error. The project 
should be spread over a period of time during the school year. It doesn't have to fit into the existing time table.

The project method develops pupils' skills. Zeidan and Jayosi (2015) maintained that skills are expertness, practiced ability, dexterity and the facility for doing something. There are different types of skills that can be developed in pupils using the project method. These skills fall into three main categories namely affective, motor and cognitive skills. Affective skills could be divided into three subcategories namely; discriminating, classifying and rules. This classification, although artificial may help us to understand the demand made on pupils to acquire and develop these skills in science. The skill of discrimination entails the ability of pupils to differentiate between objects or substances with value judgment. For instance, the pupil may be asked to discriminate between organic and inorganic compounds, osmosis and diffusion, direct and indirect current. Discrimination enables the pupils to understand the parts of a material so that they can improvise better. Classifications take its root from discrimination as it places objects into groups. Examples; Classification of elements into metals or non-metals, minor or major elements. Machines are classified into different types of levers. This requires that pupils should draw on previous experiences of properties or use observation and analysis in order to group substances. Rules are followed to carry out an operation. For example; rules for measurement, designing, and manipulation, safety rules in the laboratory. Rules are specific, meaning that one can apply particular rule to solve problem but not necessarily understanding it. For example, pupils can calculate the value of volume by placing number into gas equation but may have no real understanding of kinetic theory.

Nwakonobi (2008) identified numerous cognitive skills, namely, assessing, reflecting, prioritizing, adopting, planning and deducing. Cognitive skills draw on element, so it is important to be developed in science teaching and learning. Without showing competence in these skills, pupils cannot demonstrate an understanding of concepts and without such an understanding there may be no meaningful learning. Consequent upon this knowledge, some classroom strategies for developing cognitive skills can be outlined. Encourage elaboration of work by allowing opportunities for pupils to paraphrase and make their own note/diagram. Place emphasis on pupils designed summaries and conclusion as it creates the chances for pupils to consolidate their memory of work content and to develop vital cognitive skills e.g. reviewing. Ask pupils about similarities between object and substances. These involve comparing and contrasting. Use recall and engage the pupils in sorting and analyzing each known detail. The teacher may use spider chart and network to promote pupils processing skills e.g. reflection. The things that can interest pupils of science at the nursery/primary school level are their immediate basic needs which are food, shelter, play and solution to problem. Example, to be interestingly present and to give the child some fun, his/her basic needs must be used at least as example either for introducing the lesson or for illustrating the presentation.

Motor skills can be developed by engaging the pupils in several manipulative skills. One of the major activities that the pupils may be engaged in the project method of teaching is modeling. Modeling; the child derives a lot of fun and enjoyment which remains as interest simulators when he engages in making his own toys that can also be used to teach some scientific concepts. For example using clay to model fishes, ear, eye, modeling aerial structure 
like a kite which can be used to teach about air resistance and force of air. After using the kite to teach, the child can develop more fun of flying his kite in addition to being the architect of his own kite. The pupils can now be asked to model a plane using cardboard sheets. Several instructional materials can be modeled in science teaching. The role of the teacher is to provide the pupils with the diagram of the materials to be modeled.

\section{Strategies for Developing Scientific Skills in Primary School Pupils}

Various scientific skills can be developed in primary school pupils by providing the necessary materials and guidelines needed to develop the skills. The teacher can then guide the pupils on how to use those materials that will enhance the development of the skill in question. For instance, the under mentioned skills can be developed as follows:

Measurement of length and the construction of meter and centimeter rule from bamboo: Supply the pupils with Centimeter rule, meter rule, measuring tape, stick, assorted materials to be measured, strong rope or thread, bamboo from palm tree and graph paper. Instruct the pupils to use their hand and feet to measure the length of different materials provided. Ask the pupils to measure the materials with the thread and rope. Finally ask the pupils to measure the same material using centimeter rule, meter rule and measuring tape. Later, ask the pupils to compare the value of the measurement made with hand, feet, rope and thread with the measurement they did with the centimeter rule, meter rule and measuring tape. Now, direct the pupils on how to plot the values from the measurement on the graph paper. Guide the pupils to use the bamboo from palm tree to construct centimetre and metre rule and compare the improvised centimetre and metre rule with the standard centimeter and metre rule.

Measurement of volume and the construction of volumetric flasks from feeding bottles and non-graduated plastic bottles: Supply the pupils with measuring cylinder, feeding bottle, nongraduated plastic bottles, funnels and a bowl of water. Ask the pupils to add water to the feeding bottle and note the volume. Let the pupils carefully pour the water from the feeding bottle into a standard measuring cylinder and note whether there is a difference in the two volumes. Ask the pupils to measure different volumes of water such as $5 \mathrm{~cm}^{3}, 10 \mathrm{~cm}^{3}, 15 \mathrm{~cm}^{3}, 20 \mathrm{~cm}^{3}, 25 \mathrm{~cm}^{3}$ and $30 \mathrm{~cm}^{3}$ and pour into the non-calibrated plastic container at different times. The pupils should mark each volume on the plastic bottles and calibrate it.

Measurement of weight and construction of weighing balance: Supply the pupils with weighing balance, different materials to be weighed and different materials that will be used to construct weighing balance. Ask the pupils to place the materials provided on a weighing balance one after the other while noting the weights. Ask the pupils to note the weight of different materials in their exercise books. Ask the pupils to construct weighing balance using the materials provided.

To develop observation skill: Supply the pupils with pictures, colours, cockroaches, butterflies, frogs, lizards and varieties of plants and animals. Ask the pupils to observe and record the features of the pictures, animals, plants and colours provided. Visit the library with the students and ask them to observe the books while noting the features of the books. Visit the school garden 
and school farm with the pupils and ask them to observe the plants in the garden and farm and record their observation. Show film strips or video cassettes of plants and animals to the pupils and ask them to observe and state the features of the observations made.

To develop questioning skills: Present some materials to the pupils that will arouse their interest to ask questions. For instance, present a bird with one wing to the pupils and ask them to draw. Definitely the pupils would want to know why that bird has one wing. Write the names of some plants and animals on the board with deliberate omission of one alphabet of their names. Bring some pieces of bread with mould to the class and give them to the pupils for observation. The pupils will certainly ask why there are some outgrowths on the pieces of bread. Parents and science teachers should talk to their pupils and use interaction to motivate the pupils to talk better and better. Supply famous books on many subjects as possible especially on such science famous stories explaining the natural events around the pupils. Pupils will definitely ask questions as they read these books.

To develop the skill of design and the designing of various shapes: Pupils could improvise models of houses and buildings as the science teacher provide them with pictures of houses, shapes and buildings, cartons, top bond, scissors, razor blade, wood battings, colours and cardboard papers. In designing triangles, circles and plane figures, model of quadrilaterals and polygons, pupils could use pieces of wood and cardboard paper. Pupils could also use carton in place of first aid box. Colour should be added to the carton to give it the desired outlook. Pupils should be made to observe the pictures of buildings and houses provided and design same using the top bond and cardboard papers provided. When these skills are developed in the pupils, they can use local resources in their environment to create science equipments.

\section{Materials to be improvised}

A lot of materials need to be improvised for science teaching considering the number of pupils that enroll in school every year and the paucity of funds. Thus, a lot of materials/equipment in science needs to be improvised to help in bridging the gap of nonavailability of learning materials/equipment. The guiding principle of improvisation is that the improvised materials/equipment should not be costly than the original item and should serve the same purpose as the original item.

Presented below is a table of items which appeared ordinarily but which a creative and innovative science teacher can employ to teach basic science concepts and aid experimentation in primary science lessons. These and many similar items can be sourced from the local environment for teaching and learning. For example using lemon juice mixed with baking powder in a bottle gives out carbon IV oxide which can be used in place of fire extinguisher. Some standard items that can possibly be improvised or substituted and their uses in science teaching and learning are; 
Journal DOI: 10.46654/ij.24889849

Article DOI: 10.46654/ij.24889849.a6101119

\begin{tabular}{lll}
\hline \hline Standard original item & Improvised item & Purpose. \\
Measuring cylinder & feeding bottle & for measuring volume \\
Bunsen burner & candle/kerosene stove & for heating \\
Dropping pipette & ear/eye medicine dropper & for dropping indicators \\
Aquarium & transparent rubber container & for storing aquatic animals \\
Sodium hydroxide & dissolved wood ashes & for acid/base titration \\
Methyl orange & hibiscus flower & used as an indicator \\
A conical flask & small lucozade bottle & used for measurement \\
Ludo seed & made from carton and clay & used for teaching probability \\
Round bottle flask & dead electric bulb & for heating \\
\hline
\end{tabular}

Some local resources and their possible use in the teaching and learning process

\begin{tabular}{ll}
\hline Local recourses & Possible use \\
\hline Paw-paw leaves & To explain bleaching action in chemistry \\
Catapult for shooting birds & To explain elasticity in physics \\
Palm oil & To explain relationship between weight and floatation \\
Salting of fish & To prevent bacteria from growing/preservation \\
\hline
\end{tabular}

\section{Conclusion}

Science learning involves both process and method. The teaching and learning of science is better understood if it is taught with facilities. When facilities that are drawn from the local environment are used in teaching and learning science, it demystifies the foreign nature of science and arouses the pupils' interest, raising their moral and ego about the things in the environment. The project method of teaching science in primary schools has the potential to provide varieties of instructional materials that will facilitate the teaching of primary science. Nigeria will be a great nation if we re-direct our focus and utilize the resources in our environment for the teaching of science. 
Journal DOI: 10.46654/ij.24889849

Article DOI: 10.46654/ij.24889849.a6101119

\section{Recommendations}

In order to achieve the target of 'education for all' of the Sustainable Development Goals, through the project method of teaching basic science and technology, the following recommendations were made;

i. Pupils should be given projects of interest to work upon.

ii. The school should organize routine exhibition of locally improvised materials and give award for best items.

iii. Government should provide good working conditions for teachers to enhance creativity.

iv. Material from local environment should be used by pupils in designing improvised materials. 


\section{REFERENCES}

Federal Republic of Nigeria (2013). National Policy on Education. Abuja; Nigeria Educational Research and Development Council Press.

Landu,I. T. (2000). The use of improvisation in promoting understanding of science in the 6-3-34 system of education. Nigeria Journal of Curriculum Studies 1(viii).

Madubine, C.O. \& Ikwuanusi, E. N. (2007). A hand book of Biology methods. Owerri; Webs media communication.

Nwakonobi, F. E. (2008). Realizing the vision of NEEDS and MDGS; implication for Biology education. Journal of Science Education 8 (1) 58-68.

Oyediram, A.M. (2010). Using improvised materials to enhance the teaching of Basic Science in Primary Schools. Capacity building workshop training manual for primary school teachers in Oyo state. Proceedings of the $51^{\text {st }}$ Annual Conference of Science Teachers Association of Nigeria (STAN).

Onoja, A. I., Azoro, A. V. \& Egeruoh, A. S. (2012). Basic approach to Biology Methods 1. Owerri: Mercy Divine Publishers.

Yero, H. I. \& Bello, M. (2010). Economic Melt-down and the Teaching of Basic Science at lower and middle Basic Classes In U. Nsikak -Abasi (ed) STEM Education and Global Economic crisis. Proceedings of the $51^{\text {st }}$ Annual Conference of Science Teachers Association of Nigeria (STAN), 212-217.

Zeidan H. \& Jayosi, M. J. (2015). Science Process Skills and Attitudes toward Science among Palestinian Secondary School Students. World Journal of Education 5 (1) 13-24 